Acta Theriologica $36(1-2): 119-129,1991$.

PL ISSN $0001-7051$

\title{
Habitat use of wild boar in a French agroecosystem from late winter to early summer
}

\author{
Jean-François GERARD, Bruno CARGNELUTTI, François SPITZ, \\ Gilbert VALET and Thierry SARDIN*
}

Gerard J.F., Cargnelutti B., Spitz F., Valet G. and Sardin T. 1991. Habitat use of wild boar in a French agroecosystem from late winter to early summer. Acta theriol. 36: 119-129.

Patterns of habitat use by the wild boar, Sus scrofa Linnaeus, 1758, in an agricultural ecosystem, were studied from late winter to early summer in southwestern France, by monitoring radio- collared individuals and collecting the animals activity signs. Results showed that natural habitats are of importance for wild boars in a farmland environment, most of their activity, particularly day bedding, taking place there. Wild boars make intensive use of large woodland and heathland units. The proximity of human development did not seem to affect their activities a great deal.

Centre de Recherche en Biologie du Comportement U.A. C.N.R.S. 664, Université Paul Sabatier, 118 Route de Narbonne, 31062 Toulouse Cedex, France; Institut de Recherche sur les Grands Mammifêres, Institut National de la Recherche Agronomique B.P. 27, 31326 Castanet - Tolosan, Cédex, France

Key words: habitat use, agroecosystem, Sus scrofa

\section{Introduction}

After interspecies comparisons, socioecology has, for more than ten years, been studying the intraspecific variability of social and spatial relationships according to environmental conditions (Gautier 1982, Lott 1984, Schaal 1987). However, few authors have studied the wild boar Sus scrofa Linnaeus, 1758 in this regard (see Teillaud 1986), despite its potential to play a paradigmatic role. As a result of its broad geographic distribution (Sjarmidi and Gerard 1988), it is currently found in a wide variety of environments, from boreoalpine regions (Fadeev 1981, Singer et al. 1981, Erkinaro et al. 1982) to equatorial forests (Groves 1981), and from the steppes (Pfeffer 1961) to the temperate woodland and the dry or wet mediterranean biotopes (Franceschi 1984, Lescourret and Genard 1985, Dardaillon 1986).

Until now, most of the fundamental ecoethological investigations devoted to this species have been performed in temperate woodland (see bibliographical reviews by Mauget $e t$ al. 1984, Dietrich 1984, Gerard and Campan 1988). In the present paper, results concerning habitat preferences are reported for a wild boar population in an agricultural ecosystem. These data should help to establish an empirical data base for testing socioecological hypotheses and comparing the individual development (onto- and sociogenesis) and the biology of wild boar populations under various environmental conditions.

*Present address: Office National des Forêts, Avenue de Metz B. P. 709, 55107 Verdun Cédex, France 


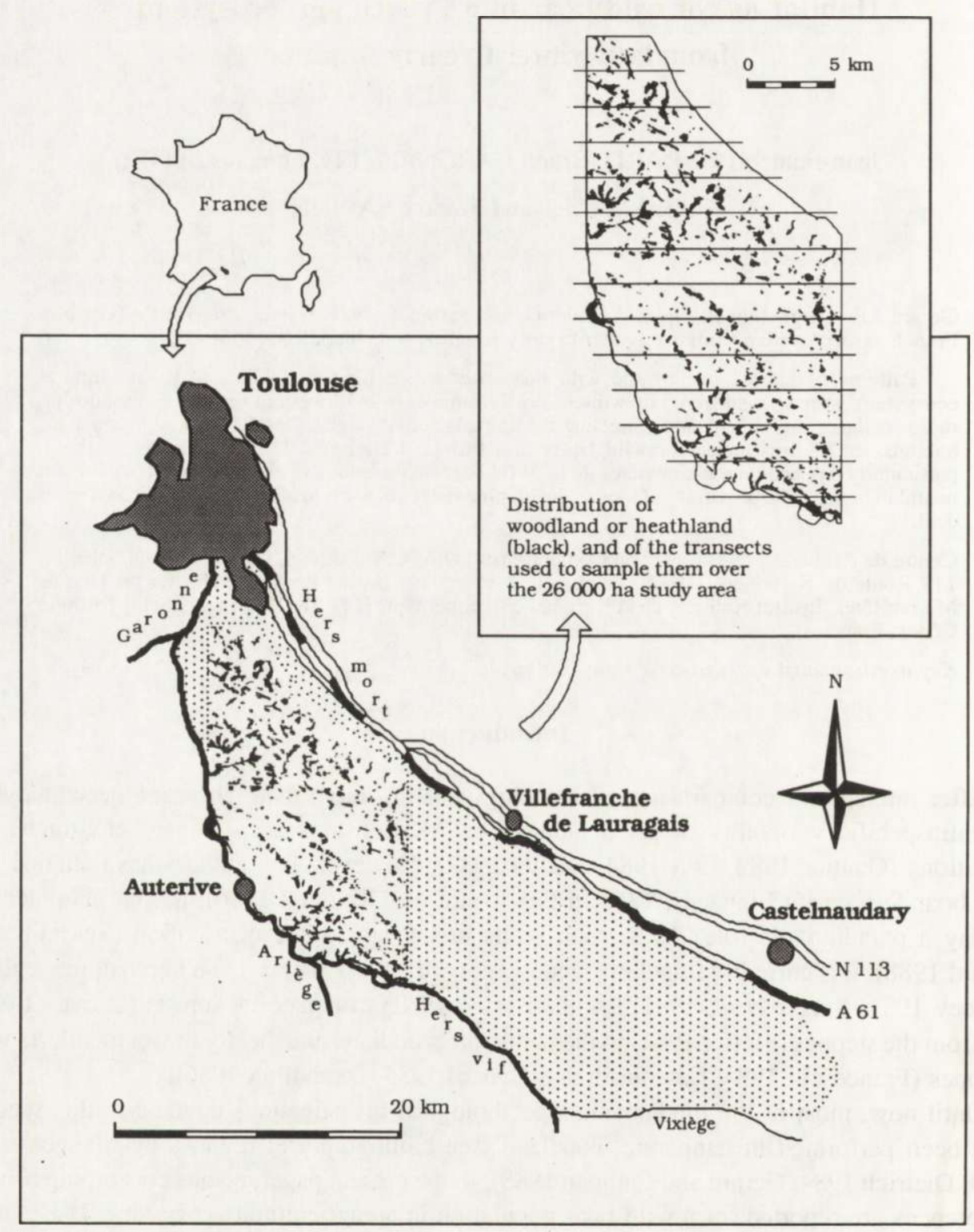

Fig. 1. Location of the Terrefort Toulousain (grey) and of the 26000 ha study area (black and white) used to determine the preferences of wild boar for various types of woodland or heathland. 


\section{Material and methods}

\section{Study area}

The study was conducted in southwestern France, in a part of the agricultural region of the Lauragais called "Terrefort Toulousain", bounded to the North-West by the town of Toulouse $\left(43,37^{\circ} \mathrm{N} ; 1,27^{\circ} \mathrm{E}\right)$, to the West and South-West by the Ariège and the Hers Vif rivers, by the Vixiège river to the South and the Hers Mort valley to the East (Fig. 1). Elevations range from 200 to $300 \mathrm{~m}$. The area consists of marl and molasse terrain and is disected by numerous small valleys.

The region is predominantly made up of large fields, mainly straw cereals (wheat and barley) covering about half of the cultivated area. Because of recurring lack of summer rain, maize culture has been progressively replaced by sorghum and protein-rich crops which are more drought-resistant. Only $9 \%$ of the area is occupied by woodland and heathland, mainly in valley floors and on steep slopes where they form small units (average 5 ha), which are evenly distributed across the landscape (Fig. 1). Woodland mainly consists of Quercus pedunculata, $Q$. pubescens and Robinia pseudo-acacia on the slopes, with Fraxinus excelsior, Alnus glutinosa and different cultivated varieties of Populus spp. in the valleys. The growth of herbaceous and scrub species often reduces ground visibility. Heathland consists of lawns of Brachypodium pinnatum, invaded to varying degrees by shrubs (mainly Prunus spinosa). There are also isolated farms and villages connected by a network of small roads located mainly on the ridges.

\section{Wild boar population}

The native subspecies is normally Sus scrofa scrofa (Groves 1981, Sjarmidi and Gerard 1988). Genetically, the population of the Terrefort Toulousain cannot however be considered to be completely 'wild': local game societies frequently make uncontrolled introductions of captive-reared animals which can sometimes be hybrids of S. s. scrofa and domestic pigs. There are on the other hand no free-ranging domestic or feral pigs in the area. Average poptlation density is particularly low and probably below 5 individuals/1000 ha (Spitz and Pépin 1985). Wild boars are mainly hunted in fall during game drives involving a small number of people.

\section{Monitoring of radio-collared individuals}

Six individuals (one adult female and five subadult males) were radio-tracked between March and July (Fig. 2). They were trapped in the northwestern quater of the study area, then relaesed on the site of capture

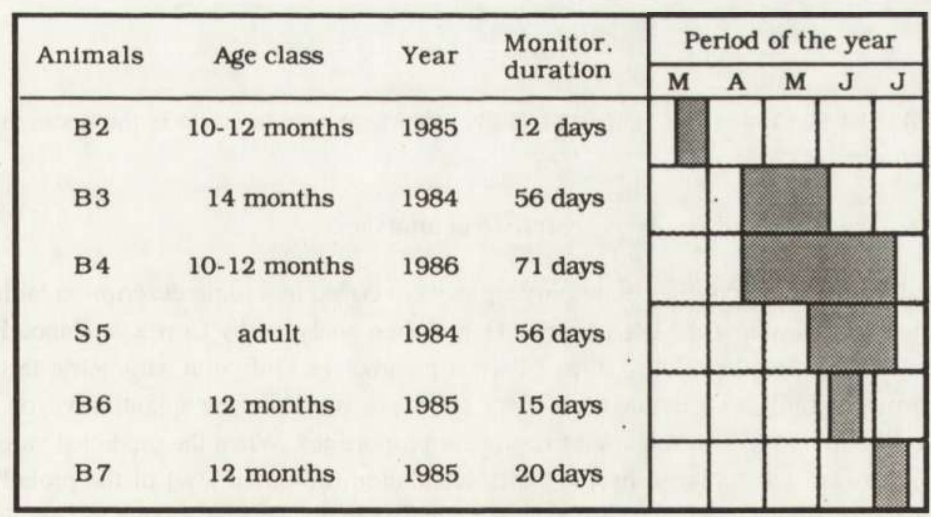

Fig. 2. Radio-tracking periods and characteristics of radio-collared animals ( $\mathrm{S}-$ sow, B - boar). 
immediately after tagging with $0.3-\mathrm{kg}$ radio-collars (see Cargnelutti et al. 1990). No drugs were used. The radio-tracking equipment was supplied by the AVM Instrument Company and consisted of SB2 and SB2 1V type transmitters. Monitoring of the animals was performed from vehicles equipped with double yagi antennas and LA 12 receivers with 'null-peak' systems. The locations of the animals were calculated relative to the position of fixed beacons (Janeau et al. 1979).

As the wild boars from this area are mainly nocturnal (Cargnelutti 1986, Gerard and Campan 1988), two types of data were recorded: daily locations of diurnal bedding sites and continuous tracking (at 10-min intervals) during first half ('evening') or second half ('morning') of activity phases. A total of 187 bedding sites were thus located and 18 continuous radio-tracking surveys of a total of six animals (corresponding to 461 locations during the activity period) were conducted.

Taking into account the theoretical accuracy of the measurements (Janeau et al. 1979, Bideau et al. 1983), each radio-location was classified according to its location within a specific cell of a $100 \mathrm{~m} \times 100 \mathrm{~m}$ map grid. Each cell of this grid was classified into one of four types of habitat for purposes of analysis (1) natural habitat (woodland and/or heathland), (2) agricultural land, (3) both of the two former types of habitat ('mixed habitat'), and (4) developed areas with no natural vegetation. The frequency of use of a given habitat was defined as the frequency of radio-locations recorded in cells of that habitat (Pietz and Tester 1982, Maublanc 1986). The area of the home range of each animal was defined over its whole radio-tracking period (Fig. 2) as the total number of grid cells contained in or cut by the minimum convex polygon including all its radio-locations.

\section{Record of activity signs}

The preferences of wild boars for different types of woodland or heathland were estimated over the whole population by recording activity signs in late winter-early spring 1986, over a 26000 ha sampling area (Fig. 1). To that end a series of West-East transects were drawn at 2-km intervals on a map (scale 1:25 000); any woodland or heathland unit cut by a transect was then investigated intensively to record activity signs. A total of 66 woodland or heathland units were thus investigated over a 53-day period. Labile signs (footprints), as well as more persistent signs such as rubbed or slashed trees (Sardin and Cargnelutti 1987), wallows or rooting sites, were recorded. Each investigated unit was also characterized by a series of parameters describing the understory vegetation, composition of the woodland, presence of water, nature of surrounding agricultural land, proximity or the presence of structures related to human activity (e.g. roads, tracks, isolated houses, villages), the area of the unit, the sinuosity of its border. The last parameter was quantified using an index $(I S)$ which is the ratio of the actual border length of the unit $(L)$ relative to the circumference of a circle with the same surface area $(S)$ as the unit being studied:

$$
I s=L /(4 \pi S)^{1 / 2}
$$

The minimum value of this index is 1 , since, for a given surface area, a circle is the geometric shape with the smallest circumference.

\section{Statistical analyses}

Data collected during the recording of activity signs were coded in a logic description table of 66 rows (one per unit visited) and 36 columns (one per parameter), and then analyzed by Correspondance Factorial Analysis (Benzécri 1973), to determine the relationships between parameters. Only non parametric tests, Mann-Whitney $U$ test and Spearman's rank correlation coefficient $R s$, were used for the quantitative or semi-quantitative variables. The likelihood ratio $G$ test was used to compare proportions. When the predicted values were too small (Cochran's rule), this test was replaced by the exact calculation (binomial law) of the probability of obtaining the observed distribution or one even more different from that expected (Fisher's exact test applied to comparisons between an observed and theoretical distribution). For multiple comparisons, the threshold of binary tests was systematically lowered to $1-(1-0.05)^{1 / c}$ (where $c$ is the number of binary comparisons), so that the probability of a type error did not exceed 0.05 (see Scherrer 1984). Tables used were those supplied by Scherrer. 


\section{Results}

\section{Habitat preference of individuals}

Habitat use during the activity period

The recorded frequency of use of the various habitats by each animal, during the activity period, can be compared to the composition of its home range in these habitats. Assuming that the expected distribution, in case of non-selectivity towards the various habitats, is the composition of the home range, three males (B2, B6 and B7) significantly avoided the immediate proximity of human habitats, whereas the two other males (B3, B4) and the female (S5) seemed indifferent to them (Table 1). The earliest monitored animal in the annual cycle B2 seemed to be the only one to prefer woodland or heathland cells on the mixed cells. This individual and B3, B4 and S5 all had a marked preference for cells including at least some natural vegetation cover over agricultural fields. B6 did not seem to prefer either of these types of cells, while B7 preferred the cultivated fields (Table 1).

These differences between the habitat preferences of individuals were highly significant (if human habitats are excluded: $G=143.03$; d.f. $=10 ; p<0.05$ ), and may be partly due to the seasons when the animals were monitored. Combining the results of the 18 continuous radio-tracking surveys across the total annual cycle (Fig. 3) indicates a general trend of the animals to leave the natural habitats and their margins between March and July. When only considering the first continuous radio-tracking of each animal (to produce independent data), there is a significant decrease across time in the frequency of use of the woodland or heathland cells $(R s=-0.829 ; n=6 ; p<0.05)$. This trend was also observed in each of the individuals (B4 and S5) radio-tracked over extended periods of time, although small sample size prevented statistical testing of this data.

This general trend does not exclude the possibility of differences between individuals or between classes of individuals (which cannot yet be verified because of our sample size): the adult female S5, for example, seemed to have a marked preference for natural habitats compared to the younger subadult males (Table 1).

Table 1. Results of binary comparison tests (all of d.f. $=1$ ) between the frequencies obtained and those expected assuming non-selectivity of the habitats on the home range, for each individual and for different habitat groups. *: significant difference for a threshold of $1-(1-0.05)^{1 / 3}=0.017$ (see material and methods). When the theoretical values are too small, the exact probability $(p)$ of obtaining the observed distribution even more different from the theoretical one, is indicated.

\begin{tabular}{lccc}
\hline Animals & $\begin{array}{c}\text { Fields with house(s) } \\
\text { versus other habitats }\end{array}$ & $\begin{array}{c}\text { Agricultural fields versus other } \\
\text { habitats without house }\end{array}$ & $\begin{array}{c}\text { Wood- and heathland } \\
\text { versus mixed habitat }\end{array}$ \\
\hline B2 & $G=20.59^{*}$ & $G=137.54^{*}$ & $G=9.09 *$ \\
B3 & $p=0.581$ & $G=7.24^{*}$ & $p=0.417$ \\
B4 & $G=2.53$ & $G=46.40$ & $G=1.52$ \\
S5 & $G=4.67$ & $G=35.65 *$ & $G=0.06$ \\
B6 & $G=11.21^{*}$ & $G=1.49$ & $p=0.097$ \\
B7 & $G=11.93^{*}$ & $G=7.41^{*}$ & $p=0.380$ \\
\hline
\end{tabular}




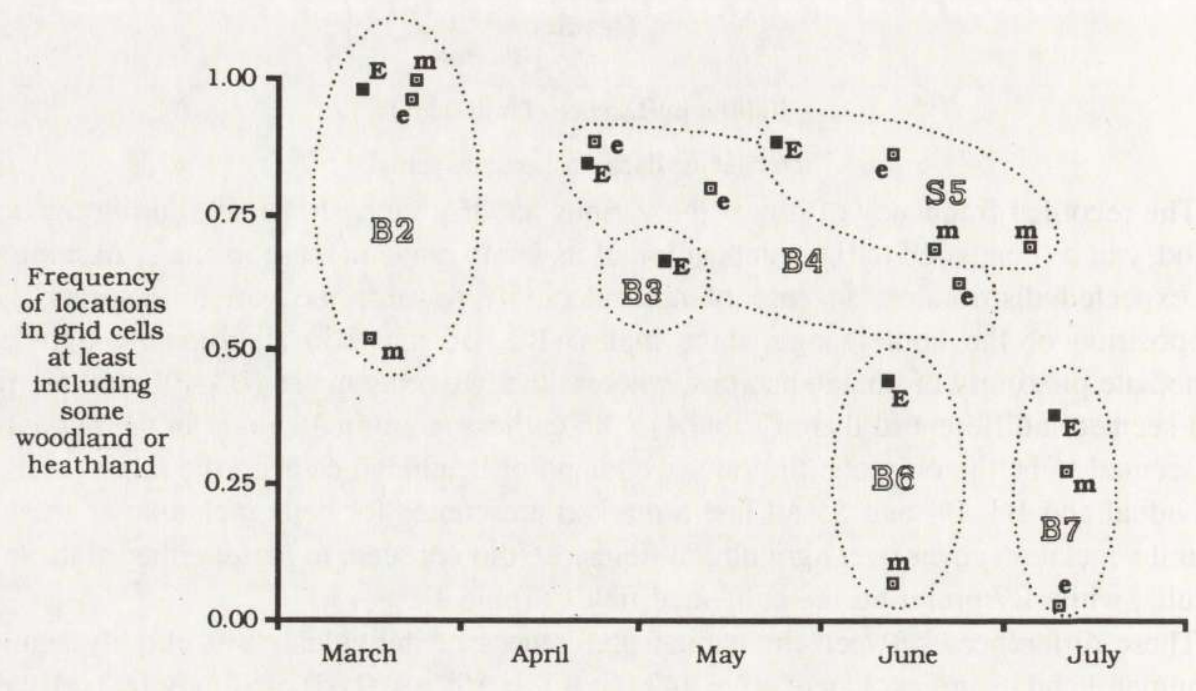

Fig. 3. Frequency of use of grid cells including at least some woodland or heathland, for each continuous radio-tracking survey during an activity phase: (m) - morning; (e) - evening. (E) - evening use to calculate the Spearman correlation coefficient (see text).

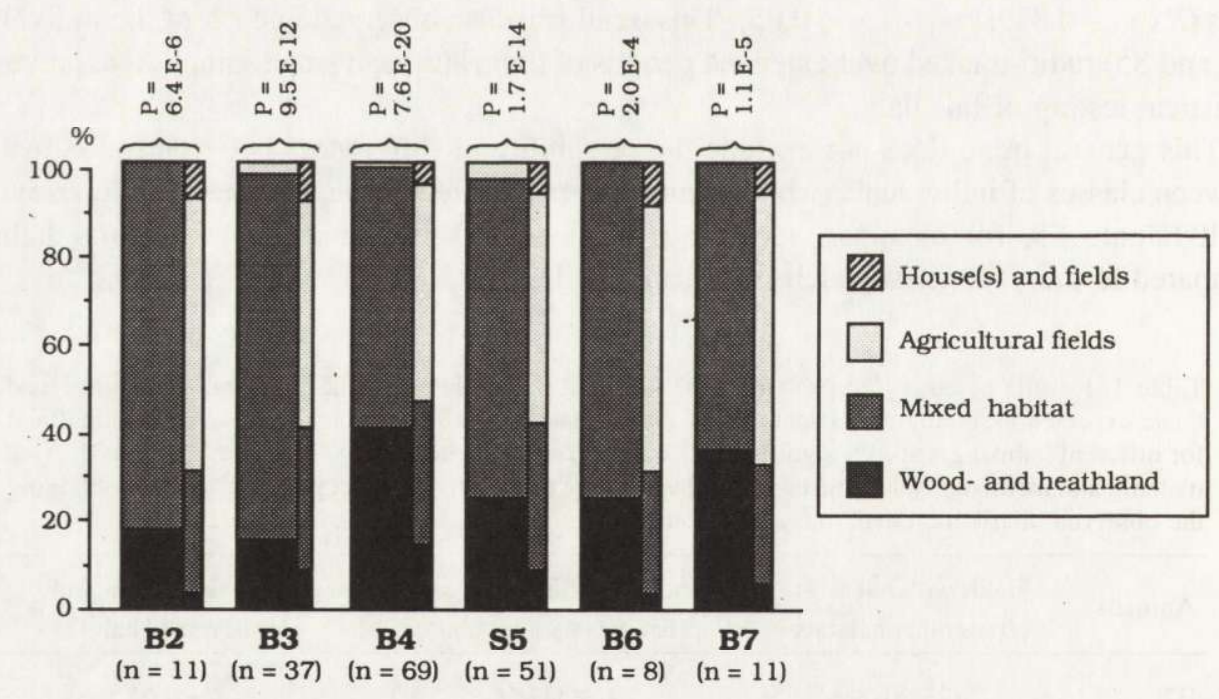

Fig. 4. Recorded frequencies of day bedding sites for each individual in four types of grid cells (left column), and proportions of these same types of habitat in its home range (right column). The probability of obtaining the recorded numbers of radio-locations in natural habitats and in pure agricultural fields respectively, or a distribution differing even more from the theoretical one, is recorded at the top of each column. 


\section{Diurnal bedding sites}

The trend of the radio-collared animals to favour natural habitats was even more marked during resting times than during the activity phases. None of the 187 located bedding sites were in the proximity of a building and only four of them were in cells composed only of agricultural fields. This trend to systematically avoid agricultural land was highly significant for each of the radio-tracked animals (Fig. 4). Visual inspections confirmed that the bedding sites recorded in mixed grid cells were mainly located within woodland or heathland habitats (see also Cargnelutti et al. 1990).

\section{Habitat preference of the population}

The activity signs of wild boars recorded in the 66 woodland and heathland units between late winter and early spring add information to habitat use by the whole population. Figure 5 shows the dispersal of the variables used to describe these units, within the space defined by the first two axes of the Correspondance Factorial Analysis. The first axis (F1) explains 18.55\% of the total variability between sampled units, whereas only $8.53 \%$ is explained by the second axis (F2). Axis 1 distinghishes units with no signs of activity from those which showed signs of any kind and characterizes these two different categories in terms of their associated habitat variables.

Thus, signs of wild boar activity are generally associated with large woodland or heathland units, a sinuous border, the presence of water, abundant oaks and dense underwood. It can be demonstrated that these 5 parameters associated with the presence or absence of activity signs are not statistically independent, and that they are particularly related to the surface area of woodland and heathland units (Table 2). Because of the structure of the environment, it is not possible to determine whether any of these 5 parameters describing the units, are more important than others in explaining habitat preference.

Variables relating to human activity (forestry or farming activity) or indicating the proximity of human infrastructures (roads, tracks, houses) are located near axis F2, suggesting

Table 2. Results of the independence tests (1) between the area of the units and various other descriptors associated with the presence or the absence of activity signs by Correspondence Factorial Analysis, (2) between the presence of footprints (within or on the border of the units) and the presence of a rapeseed field or a former maize field alongside the unit. $f$ : frequency of observation. Number of investigated units: 66 . *: significant dependence for a threshold of $1-(1-0.05)^{1 / 5}=0.010$ for the first series of binary tests; ${ }^{\circ}$ : significant dependence for a threshold of $1-(1-0.05)^{1 / 2}=0.025$ for the second series (see material and methods). d.f. $=1$ for the two $G$ tests.

\begin{tabular}{|c|c|c|}
\hline \multirow[t]{5}{*}{ Area of the unit } & Sinuosity of the border & $R s=0.57$ * \\
\hline & Many oaks $(f=48 / 66)$ & $U=136 *$ \\
\hline & Much dense underwood $(f=50 / 66)$ & $U=127 *$ \\
\hline & Presence of water $(f=54 / 66)$ & $U=142 *$ \\
\hline & Presence of signs $(f=46 / 66)$ & $U=228 *$ \\
\hline \multirow[t]{2}{*}{ Presence of footprints } & Former maize along the unit & $G=5.64^{\circ}$ \\
\hline & Rapeseed along the unit & $G=0.98$ \\
\hline
\end{tabular}



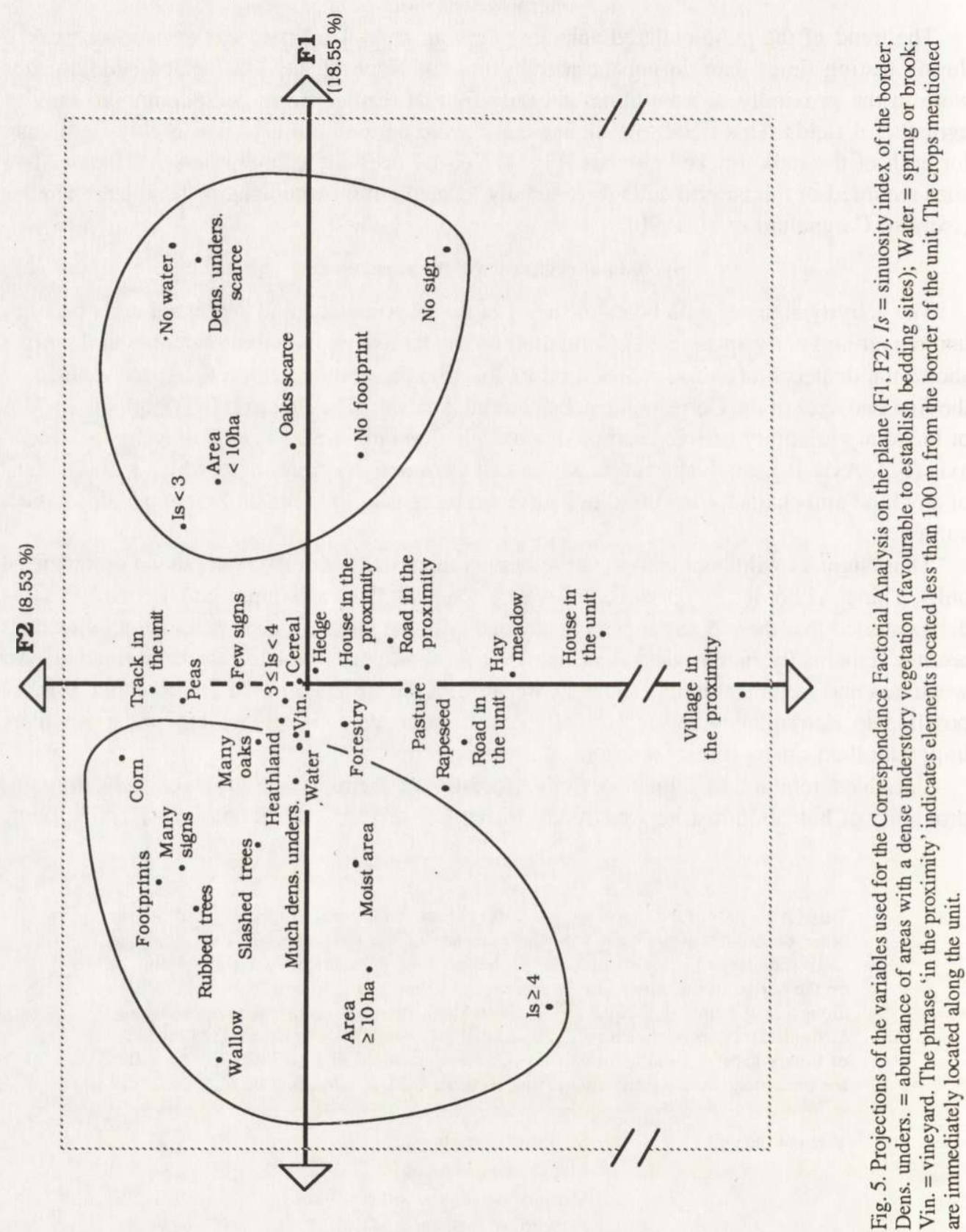
that they have a negligible effect on the presence of wild boars in woodland and heathland units. Most of the variables representing the nature of the crops located along the units, are also very close to axis 2 , and are therefore also of low importance. This includes rapeseed (Table 2), although it is located rather close, on the first axis, to parameters known to be relevant. Maize on the other hand represents a noticeable exception since the presence of footprints (labile signs indicating a recent passage at the time of recording) is not statistically independent of the presence, along the border of a unit, of a field where maize had been grown the previous year (Table 2).

\section{Discussion}

Our results show that unmodified natural habitats and their borders are of considerable importance to wild boar living in an agroecosystem from late winter to early summer. This has also been found for the roe deer Capreolus capreolus (Linnaeus, 1758), another ungulate which has inhabited the agricultural plains of Central and Western Europe for several decades (Kałuziński 1974, Maublanc et al. 1985, Cibien et al. 1989). However, the seasonal variations in the use of agricultural land are very different between the two species. In an agroecosystem, the roe deer does not spend any more time in the fields during summer than during spring, although it spends considerable time there during fall and winter (Zejda and Bauerovà 1985, Maublanc 1986). Wild boar on the other hand spends less time in cultivated fields in March, April and May than in June and July. In less agricultural environments, several authors have also reported a higher use of the fields adjacent to woodland or other natural vegetation types by wild boar (Briedermann 1976, Genov 1981, Vassant and Breton 1986, Dardaillon 1986).

These variations in the frequency of use of agricultural fields is mainly observed in active animals, since the wild boars from the Terrefort Toulousain usually seem to locate their bedding sites in natural habitats and at their borders. This observation, as well as the fact that the bedding sites are generally located in areas with dense vegetation cover (Cargnelutti et al. 1990), cannot be totally explained by efforts to seek seclusion. In this region, human presence is scarce in agricultural fields, woodland or heathland. Moreover, from late spring the straw cereal fields provide shelter as effective as that of dense thicket to an animal the size of a wild boar. Another index of the seclusion of the environment is the fact that wild boars from the Terrefort Toulousain are less nocturnal than their forest counterparts, and in particular often leave their bedding sites in the middle of the afternoon (Cargnelutti 1986, Gerard and Campan 1988). These preferences for the location of diurnal bedding sites might be explained by the search for thermal comfort or even shade provided by a 'natual roof'. According to Dardaillon (1986), the diurnal bedding sites of wild boar in the Camargue, are generally located outside of dense vegetative cover in winter and inside the cover in summer.

In the Terrefort Toulousain, wild boar seems to generally prefer the larger woodland and heathland units. This corroborates the fact that the animals generally tend to stay in the more wooded parts of the study area (Cargnelutti et al. 1990). In this region, a large woodland or heathland unit generally includes water (necessary to wallow), many oaks (and acorns) and areas of dense underwood (preferred places for bedding sites). Statistically, a large area for the unit is also associated with a sinuous border. As also seems to be the case in more forested 
areas (Vassant 1973, Herrenschmidt and Regost 1979, Genov 1981, Vassant and Breton 1986), this latter fact enables the wild boar to move into agricultural fields without moving far from woodland or heathland. In an agroecosystem, this is probably more true in winter and early spring when crop heights are low; indeed two subadult males (B6 and B7), monitored when straw cereal crops were high, were observed moving into the fields several times very far from the woodland and heathland borders.

Finally, radio-tracking shows that wild boar avoid the proximity of houses without natural vegetative cover in their vicinity. This is in agreement with the observations of Lescourret and Génard (1985) or Vassant and Breton (1986). By contrast, they frequent woodland or heathland units even if these include or are close to human infrastructures.

Acknowledgements: We would like to thank I. Lehr Brisbin, Jr., Professor at the Savannah River Ecology Laboratory (Drawer E., Aiken, South Carolina), for his encouragements and all his constructive remarks. Our thanks are also due to P. Winterton for checking the English manuscript.

\section{References}

Benzécri J. P. 1973. L’analyse des données II. L’analyse des correspondances. Dunod, Paris (France).

Bideau E., Vincent J. P., Quéré J. P. and Angibault J. M. 1983. Occupation de l'espace chez le chevreuil (Capreolus capreolus $\quad$ L., 1789). I.- Cas des mâles. Acta oecol. Ecol. applic. 4: 163 - 184.

Briedermann L. 1976. Ergebnisse einer Inhaltsanalyse von 665 Wildschweinmagen. Zool. Garten 46: 157 - 185.

Cargnelutti B. 1986. Approche écoéthologique du Sanglier Sus scrofa L. dans la région agricole du Lauragais. D.E.S., Toulouse (France).

Cargnelutti B., Gerard J. F., Spitz F., Valet G. and Sardin T. 1990. Occupation par le Sanglier des habitats d'un agroécosystème modifié lors de la mécanisation de l'agriculture. Gibier Faune Sauvage 7: 53 - 66.

Cibien C., Boisaubert B. and Maublanc M. L. 1989. Répartition du Chevreuil (Capreolus capreolus L.) dans les agroécosystèmes du nord de la France. Mammalia 53: 126 - 129.

Dardaillon M. 1986. Seasonal variations in habitat selection and spatial distribution of wild boar (Sus scrofa) in the Camargue, southern France. Behav. Process. 13: 251 - 268.

Dietrich U. 1984. Ergebnisse und Tendenzen der Forschugen am Wildschwein Sus scrofa in den Jahren 1975-1983. Säugetierk. Mitt. 31: 223 - 237.

Erkinaro E., Heikura K., Lindgren E., Pulliainen E. and Sulkava S. 1982. Occurence and spread of wild boar (Sus scrofa) in eastern Fennoscandia. Memoranda 58: $39-47$.

Fadeev E. V. 1981. On the dynamics of the northern border of the area of the wild boar in the East Europe. Biol. Nauki 9: 56 - 64. [In Russian with English summary]

Franceschi P. 1984. Quelques caractéristiques de la population de sangliers de Corse et analyses de ses échanges avec le porc domestique. Bull. Mens. ONC 85: 25 - 35 .

Gautier J. Y. 1982. Socioécologie. L'animal social et son univers. Privat, Toulouse (France),

Genov P. 1981. Significance of natural biocenoses and agrocenoses as the source of food for the wild boar (Sus scrofa L.). Ekol. pol. 29: 117 - 136.

Gerard J. F. and Campan R. 1988. Variabilité écoéthologique chez le sanglier européen comparaison des travaux français. Cahiers Ethol. appl. 8: 63 - 130.

Groves C. 1981. Ancestors for the pigs taxonomy and phylogeny of the genus Sus. Australian National University, Canberra. Dept. Prehist. Techn. Bull. 3: 1 - 96.

Herrenschmidt V. and Regost M. 1979. Contribution à l'étude éco-éthologique du Sanglier en Forêt Domaniale de Grésigne et cultures limitrophes (Tarn). Final report ISA, Lille (France).

Janeau G., Quéré J. P., Spitz F. and Vincent J. P. 1979. Le radio-tracking en forêt, expériences menées sur le Chevreuil (Capreolus capreolus). Ann. Zool. Ecol. Anim. 11: 131 - 144.

Kaluziński J. 1974. The occurence and distribution of field ecotype of roe-deer in Poland. Acta theriol. 19: $291-300$. 
Lescourret F. and Génard M. 1985. Recherches d'indices d'alimentation et connaissance des milieux exploités

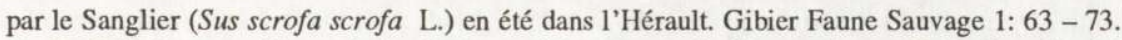

Lott D. F. 1984. Intraspecific variation in the social systems of wild vertebrates. Behaviour 88: $266-325$.

Maublanc M. L. 1986. Utilisation de l'espace chez le Chevreuil (Capreolus capreolus) en milieu ouvert. Gibier Faune Sauvage 3: $297-311$.

Maublanc M. L., Bideau E. and Vincent J. P. 1985. Données préliminaires sur la tendance grégaire chez le chevreuil (Capreolus capreolus L.) en milieu ouvert, durant l'automne et l'hiver; comparaison avec le milieu forestier. Mammalia 49: 3 - 11.

Mauget R., Campan R., Spitz F., Dardaillon M., Janeau G. and Pépin D. 1984. Synthèse des connaissances actuelles sur la biologie du Sanglier, perspectives de recherche. [In: Symposium international sur le sanglier. F. Spitz and D. Pépin, eds]. Colloques de l'INRA (Paris) 22: 15 - 50.

Pfeffer P. 1961. L'écologie du Sanglier d'Asie centrale d'après les recherches d'A.A. Sloudsky. Rev. Ecol. (Terre Vie) $108: 368-372$

Pietz P. J. and Tester J. R. 1982. Habitat selection by sympatric spruce and ruffed grouse in north central Minnesota. J. Wildl. Manage. 46: $391-403$.

Sardin T. and Cargnelutti B. 1987. Typologie des arbres marqués par le Sanglier dans une région à faible taux de boisement. Monitore zool. ital. 21: 345 - 354 .

Schaal A. 1987. Le polymorphisme du comportement reproducteur chez le Daim d'Europe (Dama $d$. dama ). Contribution à la socioécologie des cervidés. Ph. D. Thesis, Strasbourg (France).

Scherrer B. 1984. Biostatistique. Gaëtan Morin, Chicoutimi (Canada).

Singer F. J., Otto D. K., Tipton A. R. and Hable C. P. 1981. Home ranges, movements, and habitat use of European wild boar in Tennessee. J. Wildl. Manage. 45: $343-353$.

Sjarmidi A. and Gerard J. F. 1988. Autour de la systématique et de la distribution des Suidés. Monitore zool. ital. 22: $415-448$.

Spitz F. and Pépin D. 1985. Occupation de l'espace par le Sanglier en zone de grande culture. Proc. of the XVIIth Congress of the Internat. Union of Game Biol., Brussels: 953 - 959.

Teillaud P. 1986. La vie sociale chez le sanglier co-émergence collectivité - individualité. Cahiers Ethol. Appl. 6: $157-184$.

Vassant J. 1973. Contribution à la compréhension du phénomène des dégâts de sanglier et leur évolution. Final report ENITA, Dijon (France).

Vassant J. and Breton D. 1986 . Essai de réduction de dégats de sangliers (Sus scrofa scrofa) sur blé (Triticum sativum) au stade laiteux par distribution de maïs (Zea maïs) forêt. Gibier Faune Sauvage 3: 83 - 95.

Zejda J. and Bauerovà Z. 1985. Home ranges of field roe deer. Acta Sci. Nat. (Brno) 19: 1 - 43.

Received 17 September 1990, accepted 2 July 1991.

Acta Theriologica $36(1-2): 129-130,1991$.

\section{BOOK REVIEW}

\section{Wild Pigs of the United States}

Wild Pigs of the United States. Their History, Morphology, and Current Status. J. J. Mayer and I. L. Brisbin, Jr. The University of Georgia Press, Athens and London, 1991, 313 pp. ISBN 0-8203-1239-8.

The book is devoted to wild pigs and more precisely to certain aspects of their presence in North America. These aspects include: history of introductions, comparative morphology, and current status of pigs in USA. The book says nothing about biology and ecology of these animals. Authors were interested mainly in physical presence or absence of pigs, as well as in morphological characters helpful in tracing their origin. 